\title{
Development of Students Creativity Element in Technical Education and Vocational Training: Systematic Review
}

\author{
Abd Rahman Wahab, Muhammadd Sukri Saud. Yusri Kamin, Zuhaila Saleh
}

To Link this Article: http://dx.doi.org/10.6007/IJARBSS/v12-i1/12200

DOI:10.6007/IJARBSS/v12-i1/12200

Received: 09 November 2021, Revised: 15 December 2021, Accepted: 03 January 2022

Published Online: 22 January 2022

In-Text Citation: (Wahab et al., 2022)

To Cite this Article: Wahab, A. R., Kamin, M. S. S. Y., \& Saleh, Z. (2022). Development of Students Creativity Element in Technical Education and Vocational Training: Systematic Review. International Journal of Academic Research in Business and Social Sciences, 12(1), 2537-2547.

Copyright: (c) 2022 The Author(s)

Published by Human Resource Management Academic Research Society (www.hrmars.com)

This article is published under the Creative Commons Attribution (CC BY 4.0) license. Anyone may reproduce, distribute, translate and create derivative works of this article (for both commercial and non0-commercial purposes), subject to full attribution to the original publication and authors. The full terms of this license may be seen at: http://creativecommons.org/licences/by/4.0/legalcode

Vol. 12, No. 1, 2022, Pg. $2537-2547$

Full Terms \& Conditions of access and use can be found at http://hrmars.com/index.php/pages/detail/publication-ethics 


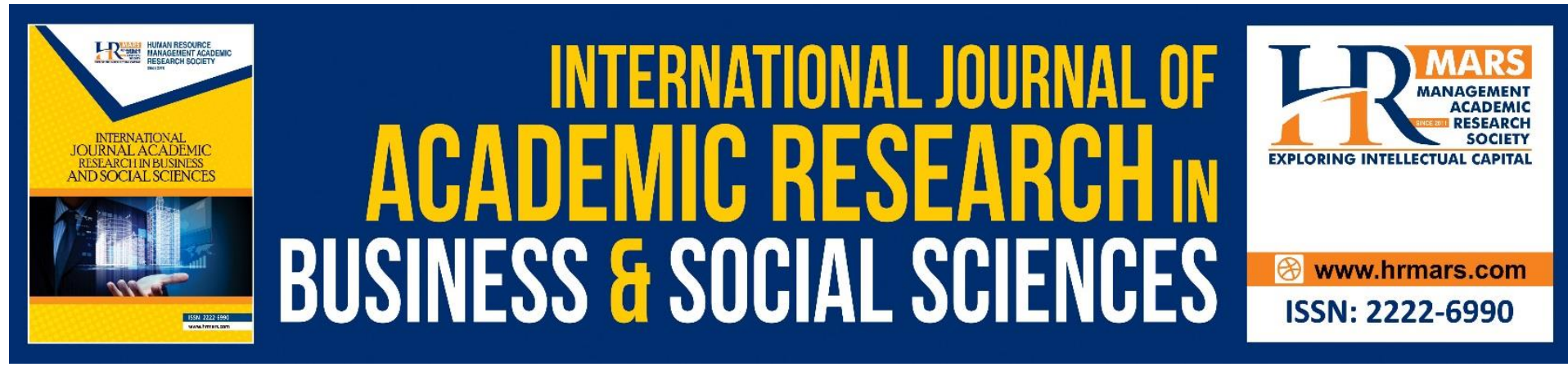

\title{
Development of Students Creativity Element in Technical Education and Vocational Training: Systematic Review
}

\author{
Abd Rahman Wahab, Muhammadd Sukri Saud. Yusri Kamin, \\ Zuhaila Saleh
}

Faculty of Social Sciences and Humanities, Universiti Teknologi Malaysia

\begin{abstract}
The aim of this study is to identify the creativity elements for technical education and vocational training (TVET) students in Malaysia. The significance of this study is to meet the needs of the industry which require employees to be creative and to help TVET institutions increase the creativity of their graduates. This study utilize Library research approach to gather data from several sources such as journals and electronic media that will explore and identify the elements/construct in student creativity instrument. The study have identified six elements related to the creativity element, namely; intelligence, knowledge, thinking style, personality, motivation and environment.
\end{abstract}

Keywords: Students' Creativity Element, Intelligence, Environment, Personality, Motivation and TVET

\section{Introduction Issues of student Creativity in TVET}

The solution to the issue of human capital and the country's skilled labour market is through TVET education. UNESCO (2015b) describes TVET as, "education, training and skills development related to various fields of employment, production, services and livelihoods, encompassing work -based learning and continuing training and professional development that can lead to qualifications. TVET can be formal in nature. (provided by educational or training institutions and leading to certification), informal (training that takes place outside the formal system) or informal (learning that results from activities of daily living related to work, family or leisure) (UNESCO, 2010). The potential of technical and vocational education and training (TVET) to drive the progress and transformation of society is widely recognized. The European Union (EU) refers to TVET as, "the engine of economic development and international competitiveness" which means TVET's ability to contribute to greater humanism and economic prosperity which is sustainable and fair in terms of social is vastly acknowledged (Wheelahan and Moodie, 2016; UNESCO, 2015a).

The production of high quality or fully-skilled TVET graduates, according to an article in the British Council: The UK Skills System, is a combination of skills that need to be possessed by all TVET graduates namely vocational skills, core skills and employability skills. According to Tan \& Nor (2017) employability skills are the main competencies that need to be effectively applied in the workplace. Khayati et al (2017) defined employability skills as non -technical 
skills and that these skills are important in all areas of employment. The country needs to provide balance and address the gap between the competency level of the national workforce to the international standards as a measure to ensure that we have competent graduates to penetrate the local and foreign job markets. The main weakness of TVET graduates as of industrial feedback is from the aspect of employability skills as well as showing poor work performance (Zulkefli et al., 2020).

A study by Artess et al (2017), stated the main problem of employers not taking technical graduates to work with them is because most of them rely solely on their academic qualifications to get jobs and lack non-technical skills competencies such as creativity and problem solving. The problem of concern is that graduates are said to be unable to provide creative views and ideas where in Ramlee's (2018) study, it was found that employers from the manufacturing industry in Malaysia now give the view that technical graduates in Malaysia have more than adequate technical skills, however employers feel less satisfied in terms of creativity and problem solving skills which are part of the employability skills that are not mastered among these technical graduates.

\section{The Important and Industrial Need of Creativity}

The past Malaysian Labour Day 2017 celebration themed "Creative Workers Originate Innovations" was very significant to all employees and showed the importance of creativity in working. Creative and innovative employees can increase productivity whilst helping to boost one's personal household and national income. Industries now place great emphasis on the creativity and innovation aspects of their workforce to ensure that their products can successfully penetrate the market for them to continue to compete with other products (Khayati et al., 2017).

Majority of organizations or industries seek employees who are holistic in planning resources and generating organizational productivity. Among the methods and approaches used in ensuring that the employee has creativity, organizations usually provide tests to each job applicants with some form of testing to see how relevant the applicant is to the organisation and to test whether he is able to provide solutions to a given case study (Nasyitah et al., 2017). The world of work is also growing rapidly and full of competition as well as technological sophistication which is also one of the factors the importance of the application of creativity for an employee. Griffin and Annulis (2017) explain the creativity is an approach that requires a combination of skill, sharpness of mind, experience, and also training for problem solving. It is also able to encourage a variety of new ideas that will benefit $n n$ organization.

In terms of the employment aspect, an individual needs to apply the concept of creativity into the organization while working (Brostrand, 2016). Using intellectual creativity, an employee should try to make some action plans and work model development plans to see the advantages and disadvantages of each model planned. This is because, organizations need flexible planning. Flexible planning needs to be designed and developed by employees with high level of creativity. Flexible planning is typically done to avoid losses and to aid usability and holisticness in organizations (Brostrand, 2016). A person with a higher level of creativity has the right mindset to adapt to the environment and to evaluate the effects and implications of something that has been done. This ability in being creative is one of the highest sought-for competencies in the labour market demand of workers (Krawjewski \& Callahan, 2018). Therefore, the propensity of the candidate to be employed will be assessed 
through the ability and excellence of conducting a given case study. The organization will also evaluate and consider each answer submitted to evaluate the cost, energy, time and amount of human capital required to solve the problem. Creative individuals are typically selected as employees compared to those who are less creative (Khayati et al., 2017). This is because, creative employees in particular have higher level of thinking and are able to solve problems competently. In addition to thinking ability, organizations also see targets in the long run as they do not only contribute in the job's and individual development, but also contribute towards the direction of the organization globally (Bekri, 2017).

\section{Problem Statement}

The results of the literature review have proven that there is a lack of studies related to creativity that combine the exploration and development of elements of creativity, especially for students of technical education and vocational training. If any, most of the research produced are adopted and adapted from existing models from abroad. Too few researchers produce models, frameworks or instruments related to the development of student creativity element by exploring and validated by local creativity experts. Existing research are mostly developed to look at relationships and most factors have been built based on Classical Test Theory (CTT) and use multidimensional research such as factor analysis. Therefore, this study is very significant because it takes into account all the spaces and limitations of previous researchers by exploring all domains related to creativity.

The absence of creativity research affects Institutions of Higher Learning (HEIs) in improving the employability of graduates and preparing students for the workplace in an ever -changing industry. Today's challenging conditions have increased stakeholder's pressure on universities, particularly pressure from the industry, to ensure that students are equipped with more than just academic skills. Griffin and Annulis (2017) found that the most common complaint of employers is around the recent graduates who do not have the creativity to make decisions and solve problems. These graduates are from universities that produce students whom are loaded with theories without the knowledge to apply them. Indeed, this problem makes it difficult for TVET instructors to increase student creativity due to the lack of specialization or focus according to the needs of the industry and current needs. If there is any research on the dominant elements in increasing students' creativity, it will facilitate the teaching focus of the teaching staff.

Therefore, with the problems and effects of the absence of research as stated, the study to develop an to increase the creativity of TVET students is through the construction of Student Creativity Element which possesses creativity constructs and is obtained from industry experts and feedbacks. Based on the literature review, it is also found that knowledge, thinking style, personality, motivation, environment and intelligence are important variables in the production of creativity of technical education and vocational training (TVET) students in Malaysia.

\section{Objectives and Research Questions}

This study aims to identify a student creativity elements based on document analysis and the objectives to be achieved in this study are:

- Exploring student creativity constructs of TVET students.

The goal of this study is to get answers to the questions that have been formed. In order to achieve the first objective of the study which is to explore the construct of creativity in the 
formation of the creative character of TVET students, then the research questions that need to be answered are $n$ :

- What are the constructs of creativity to enable the develop Student Creativity Element to be formed?

- What are the construct dimensions to enable the develop Student Creativity Element to be formed?

\section{Literature Review}

The main theoretical constructs related to creativity that has been applied is from Sternberg \& Lubart (1991). There are theories and concepts that support this research, based on previous studies that regards the relationship between the construct and creativity itself. Through the theoretical framework, the indicators are built based on six basic variable concepts before the interview is conducted, namely; knowledge, intelligence, thinking style, personality, motivation and environment. Researchers develop the constructs with regards to the authors so that the research is conducted with combinations of ideas from creativity experts. Based on the researcher's literature review, there is no specific or final constructs to serve as a guide in the construction of students' creativity. The results of this study will be a starting point in identifying constructs in building this students' creativity instrument.

There are six constructs that influence the development of students' creativity, namely intelligence, knowledge, personality, thinking style, motivation and environment. Intelligence is one of the qualities possessed by human beings. Intelligence according to Sternberg (2006) is a mental activity directed towards the purpose of adapting to the real natural environment of one's life, and to choose and shape that environment. Guilford (1975) explained that the definition of intelligence relating to creativity is the ability of the left and right brain to process information and solve problems. Knowledge in this study refers to a specific discipline practised by a person, that in order to be creative, a person needs to be knowledgeable in a field. With knowledge one will become an expert in a field. Knowledge is the basis for the birth of ideas and creativity.

Personality carries the meaning of a concept that describes a person's selftemperament. Personality is defined as the result of a fusion of the physical, mental and emotional disposition as well as how one acts in his social bubbles, as perceived by other individuals. Thinking style according to Zhu \& Zhang (2012) is the difference in approach to a task and the conflict of opinion with the respective abilities to see, learn and think. Sternberg (2006) also stated that the style of thinking is not an ability, rather, a way of activating the ability within the individual himself. Motivation according to Amabile (1996) is the passion that is driven by the strength of the internal and external force to achieve a certain goal. Özdemir et al (2021) defines motivation as the outcome of the process of both external and internal nature of a person that increases the spirit and consistency of a person in performing an action to achieve a targeted goal. Bronfenbrenner (1986) explains that the environment is a complex extrinsic force that can influence an individual's behaviour. The environment here can be perceived as things around the individual including the physical, climatic, sociocultural, political and interactions among humans and the natural surroundings.

\section{Methodology}

This research is a literary research. The research was conducted through a review of scholarly sources such as books, journal articles, and theses on creativity. It provides an 
overview of key findings, concepts and developments related to the research problem or questions in this study.

\section{Findings and Discussion}

Sternberg \& Lubart (1991) put forward the theory of creativity as the guide or the foundation of this study. They put forward six constructs or the dependent variable keys as the pillars for creativity. Here are the findings and reviews for each of the elements of creativity.

\section{Intelligence and Creativity}

Guilford in Azhar (2004) stated that the relationship between intelligence and creativity contains several capabilities, namely:

i. Sensitivity to Problems. Most creative individuals are very sensitive to the existence of problems around them. They are aware of the need for them to invent new tools or ways to solve the problem. They are aware of the lack of things around and they quickly become aware of the presence of strange, unusual and inconsistent things. These qualities allow creative individuals to constantly see new problems as well as giving them the opportunity to use their creativity to solve these problems.

ii. Fluency. Creative individuals have the ability to publish a wide range of ideas in all categories. It is this ability that can produce diverge meanings of thoughts.

iii. Flexibility. Creative individuals have the ability to adapt to changes in context. They are able to respond in any situation, time and place.

iv. Originality. Individuals who possess this trait are able to portray qualities such as giving quick responses and unusual responses, as well as being able to see insignificant connections between ideas.

\section{Environment and Creativity}

Environmental factors also influence the character development of creative students. Several psychologists have conducted studies related to individual development and put forward various types of theories. Among the several major theories on the stage of individual development are Havighurst's theory of socio-cultural development, Piaget's theory of cognitive-physical development, Freud's Theory of Development, Bandura's Theory of Social Learning and Erikson's Theory of Physical Emotional Development. According to Bronfenbrenner (1986) the study of psychologists, human development occurs in terms of physical, cognitive, emotional, social and spiritual changes that are influenced by environmental factors. Among the environmental factors are:

i. Parental Upbringing Factor. Parental upbringing also affects the cognitive and creative development in students. In essence, a family upbringing can be divided into four sections which are authoritarian, authoritative, ignorance and indulgence.

ii. Peers Influence Factor. Peers play a role in the development of an individual. Peer influence is important in one's intellectual, personality, emotional and social development. Children who associate with diligent peers will enhance their intellectual development and potential to reach the optimum level. Children who socialize with well-mannered peers will absorb positive moral values from them.

iii. Teacher Factor: Paladino (2008) recommended that teachers provide an environment that can help to stimulate students' creative behaviour. And to do so, teachers need 
to take into account three main factors namely physical, mental and emotional readiness of the students.

iv. Technical Resources Factor. The influence of technical resources and mass media can have a positive impact on the development of children's creativity, but it depends on how it is received and used. Technical resources refer to information that is obtained from reading materials such as printed media, newspapers, magazines, books, advertisements and electronic media such as film, radio, television, computers, and the internet.

\section{Thinking Style and Creativity}

In general, the creative thinking style is present in every individual, but it depends on how the individual utilises his mind and level of thinking at the optimal level. Creative thinking is not a mystical thing because it is a process of careful thinking as it is done against other forms of thinking. What distinguishes creative thinking from other forms of thinking is the characteristics, methods and processes that need to be gone through. Mohd Azhar (2004) argue that creative thinking is characterized by the ability to see things from various angles. This style also produces a variety of ways to do things. When thinking using a creative style, the goal of thinking is to produce a variety of perceptions, concepts, ideas, ways to solve problems, ways to resolve conflicts, inventions and things of the same sort. They also specified that there are several ways and micro approaches that can be used to generate thinking style and creative ideas, as stated below:

\section{Personality and Creativity}

Davis (1999) had short-listed the qualities and personality of someone who is said to be creative. Creative personalities according to Davis are:

i. Curious. Love to experiment, show interest in, like listening to the idea of others, like to ask lot of questions, open-minded to things that are not commonly rational, and like challenging situations;

ii. Confidence. The attitude of optimism towards targeted goals that can be seen through one's reactions, conversations and actions;

iii. High perseverance and efforts. Always ready and eager to face problems and challenges, high-spirited and not easily discouraged;

iv. Constructive dissatisfactions: Creative individuals who are dissatisfied about what has been achieved, will strive to see new things that can be explored and enhanced;

v. Belief in own creative ability. The habit of doing creative things and like to be creative. Creativity Awareness is a common and important trait possessed by a creative person;

vi. Seeing problems as opportunities, i.e. the ability to be prepared to see problems from multiple perspectives with an open mind. A prominent quality of a creative person is he always sees problems as challenges that needs to be resolved and not to be left unattended;

vii. Willingness to take risks: The attitude of not minding the consequences of becoming different. Rejecting limits imposed by other people;

viii. Always eager to look into new areas to develop creativity and innovation, always open to new ideas, not bothered by things that are new, different, or unfamiliar;

ix. Having deep interest in the physical phenomenon that takes place in one's surrounding environment; 
x. Keen and positive to uniqueness. Having positive attitude towards uniqueness is the most basic characteristic of a creative individual, this trait will be evident for individuals who often do something outside of one's norm;

xi. Committed and responsible for the production of new creative ideas. This quality is portrayed through diligence in completing a project as well as the ability to direct one's motivation to achieve a desired goal.

\section{Motivation and Creativity}

According to Cropley (2001), the characteristics of creativity are divided into three aspects: cognition, self and motivation. Creativity does not only depend on the ability to think, there are other factors that influence a person's creativity namely the ability or desire and motivation to evoke a person's creativity. Hutchinson (2003) pointed out that the characteristics of creativity are divided into two aspects namely cognitive aspects and noncognitive aspects. This study believes that it is not enough to involve cognitive creativity alone, as non-cognitive aspects and motivations also play an important role in stimulating, sustaining, and guiding creativity to achieve certain goals. It is understandable that the characteristics of creativity cover many aspects, not just behaviours that involve thinking skills.

In the theory of creativity by Amabile (1996), it is stated that there are three main components in the construction of creative individuals, namely; professional knowledge, creative thinking skills and motivation. Expertise refers to one's capability in a provided field. Each person has expertise in their respective area, which makes this person different from the others. Motivation is internal and external encouragements that motivate individuals to work harder, be immune to difficult situations, and be eager to change. Amabile (1983) elaborates on one of his theories namely the creativity component theory. This theory is intended for use in research on psychological and organizational creativity. It describes the creative process and the various influences on the process and its outcome. This theory has two important assumptions. First, the level of creativity that is commonly found in everyday life, up to the highest level of creativity where it is found in creations, scientific discoveries and works of art. Second, the level of creativity that can be found in the work of an individual.

\section{Knowledge and Creativity}

According to Rawlinson (2017), there are two views to explain the relationship between knowledge and creativity. The first view is the incompatible relationship between knowledge and creativity. Having too much insights in a particular field may limit an individual's creativity because when a person knows too deeply on how things are done, the individual will not be able wander outside of the box to develop new ideas. The second view is, an individual's capability to produce creative ideas are highly dependent on the depth and breadth of knowledge that he has in the particular field. He stressed that there is a relationship that is positive between creativity and knowledge. Before an individual is able to produce a product that can truly be considered creative, one must first be an expert in the field which might take 10 years or more. During the ten years, one of the activities that must take place is a deliberately planned training to improve achievement or performance in a specific skill. Amabile (1983), states that one of the important components that must exist before a product can be produced is having expertise in the field or in the related domain. One's expertise in a particular field can help to enhance one's creativity if the information and domains are stored accordingly in one's mind. 
According to Arifin et.al (2004) intellectual intelligence without creativity cannot result to an extraordinary imagination and visualization. He lists the importance of knowledge and its relationship with creativity, namely:

i. We can only generate ideas that are genuine and helpful when we have profound knowledge in a particular field.

ii. Knowledge boosts one's creativity to produce new and unique ideas.

iii. With knowledge and expertise in a field, one can produce a high-quality and valuable product. Knowledge encourages individuals to think of bigger ideas.

iv. Knowledge can help us to see the good in inadvertent situations.

\section{Conclusion}

Figure 1 shows a summary of the findings on constructs creativity and its sub-constructs based on theories, models and studies of creativity experts.

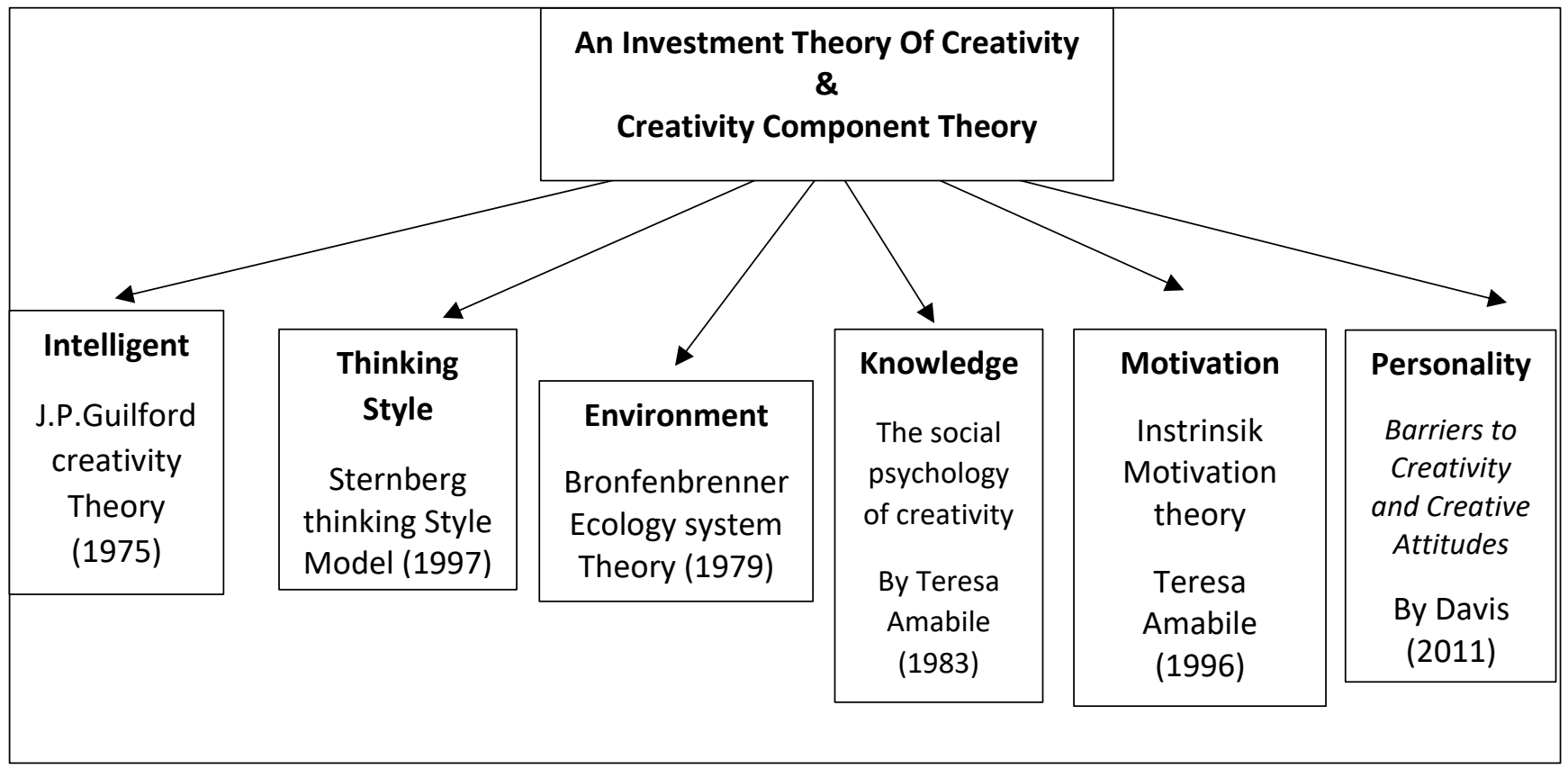

Figure 1: summary of the findings on constructs creativity based on theories, models and studies of creativity experts.

\section{Reference}

Amabile, T. M. (1996). Creativity in context. Boulder: Westview Press.

Amabile, T. M. (1983). The social psychology of creativity: A componential conceptualization. Journal of Personality and Social Psychology, 45, 357-376.

Arifin, Y., Mohd, B. H., \& Azhar, H. (2004). The influence of emotional intelligence on organizational commitment andjob satisfaction of employees in public and private sector. In Beijing Conference

Baer, J. (2011). Four (more) arguments against the Torrance Tests. Psychology of Aesthetics, Creativity, and the Arts, 5(4), 316-317. https://doi.org/10.1037/a0025211

Boroujerdi, S. S., \& Hasani, K. (2017). The survey thinking style and its relation with creativity in physical education teachers. International Journal of Educational Management, 28(4), 400-412. https://doi.org/10.1108/IJEM-05-2013-0084 
Brostrand, H. L. (2016). Tilting at Windmills: Changing Attitudes toward People with Disabilities. Journal of Rehabilitation. 72(1).

Bronfenbrenner, U. (1986) Ecology of the family as a context for human development: Research perspectives. Developmental Psychology, 22, 723-742.

Bekri, R. (2017). E-Portfolio Indicator for Competency Assessment and Virtual Learning in Malays Skills Certification. Journal for Technical and Vocational Education and Traning in Asia. 4, 1-14.

Cropley, A. J. (2001). Creativity in Education and Learning a guide for Teachers and Educators. London: Kogan Page Limited.

Davis, G. A. (1999). Barriers to Creativity and Creative Attitudes. Runco, M.A \& Pritzker, S.R (Eds). Encyclopedia of Creativity. California: Academic Press

Hutchinson, L. (2003). Educational environment. Bmj, 326(7393), 810-812.

Herpiana, R., Rosidin, U., \& Abdurrahman, A. (2019). Development of Instruments to Train Critical and Creative Thinking Skills in Physics Assessment for High School Students' Learning. In Journal of Physics: Conference Series (Vol. 1155). Institute of Physics Publishing. https://doi.org/10.1088/1742-6596/1155/1/012046.

Fischer, C., Malycha, C. P., \& Schafmann, E. (2019). The influence of intrinsic motivation and synergistic extrinsic motivators on creativity and innovation. Frontiers in Psychology, 10(FEB). https: // doi.org /1 0.3389 / fpsyg.2019.00137

Griffin, M., \& Annulis, H. (2017). Employability skills in practice: The case of manufacturing education in Mississippi. International Journal of Training and Development, 17(3), 221232.

Guilford, J. P. (1975). Varieties of creative giftedness, Quarterly, 19, 107-121

Kim, K. H. (2004). Confirmatory factor analyses and multiple group analyses on the Torrance Tests of Creative Thinking.Poster presented at the Research Symposium: The Preparation of Educators, Athens, GA. Sponsored by Georgia Systemic Teacher Education Program

Krajewski, J. dan Callahan, J. (2018). Service-Learning: A Strategy for Vocational Training of Young Adults with Special Needs. Journal for Vocational Special Needs Education. 21(1), 34-38.

Madar, A. R., Sun, C. E., Hamid, H. (2019) Facilitating torrance test of creative thinking use in malaysian TVET research: The initial step offinter-rater reliability determination.Journal of Technical Education and Training, 11 (1), pp. 100-108

Razip, M. B., Seth, S., Ellany, L. M. (2013). Construction of Creative Attitude Instrument Among Form Four Physics Students of Johor State Boarding Schools. 2nd International Seminar on Quality and Affordable Education (ISQAE 2013), 2012 (Isqae), 391-394.

Abd Hamid, M. A. (2004). Creativity Theoretical \& Practical Concepts. Johor: Universiti Teknologi Malaysia

Khayati, N. B., Isa, M. H., and Khadijah, A. R. (2017). Attitudes in Project -Based Learning towards Student Achievement at Perak Polytechnic. Articulation Ink Builds the Ummah. $3(1), 1-14$.

Özdemir, H. Ö., Kan, M., Doğan, H. G., \& Kan, A. (2021). Intrinsic motivation for creativity of agricultural holdings in Kirşehir province of Turkey. Ciencia Rural,51(3), 1-15. https://doi.org/10.1590/0103-8478cr20200112

Paladino, A. (2008). Creating an interactive and responsive teaching environment to inspire learning. Journal of Marketing Education, 30(3), 185-188. 
Sternberg, R. J., \& Lubart, T. I. (1991). An investment theory of creativity and its development. Human Development, 34(1), 1-31

Sternberg, R. J. (2006). The nature of creativity. Creativity Research Journal. Routledge. https://doi.org/10.1207/s15326934crj1801_10.

Sternberg, R. J. (1997). Thinking Style. Cambridge University Press

Rawlinson, J. G. (2017). Creative thinking and brainstorming. Routledge.

Ramlee B. Mustapha (2018). The Role of Vocational and Technical Education in the Industrialization of Malaysia as Perceived by Educators and Employers. Doctoral Dissertation. Purdue University.

United Nations Educational, Scientific and Cultural Organization (UNESCO). 2010. Guidelines for TVET policy review, Paris.

-. (2012). Transforming TVET: Building skills for work and life (Shanghai Consensus): Recommendations of the Third International Congress on Technical and Vocational Education and Training, Paris.

-. (2015b). EFA Global Monitoring Report 2015: Education for All 2000-2015- Achievements and Challenges, Paris.

-. (2016a). Education 2030: Towards inclusive and equitable quality education and lifelong learning for all. Incheon Declaration and Framework for Action, Paris.

- . (2016b). Strategy for technical and vocational education (TVET) (2016-2021), Paris

Nasyitah, N. A., Balkhis, S. A., Najihah, N. R., Mai, S. A., Nor, A. (2017). Sains Humanika. 9(5), 59-66.

Wheelahan, L., \& Moodie, G. (2016). Global Trends in TVET: A framework for social justice. Education International, Brussels.

Tan, K. H., \& Nor Hazwin, A. H. (2017). Generic Skills Profiles for hospitality graduates: the perspective of polytechnic lecturers. In :. 2nd World Congress on teacher education for TVET 2017 (pp. 126-137). Batu Pahat: Tun Hussein Onn University

Zulkifli, N., Hamzah, M. I., \& Abdul Razak, K. (2020). Creativity driving factors among polytechnic students. Asian People Journal (APJ), 3 (2), 77-85.

https://doi.org/10.37231/apj.2020.3.2.210

Zhu, C., \& Zhang, L. F. ( 2012 ). Thinking Styles and Conceptions of Creativity Among University Students. An International Journal of Experimental Educational Psychology. 31(3): 361375. 